Bangladesh J. Zool. 42(1): 35-44, 2014

\title{
NESTING COLONIES OF LITTLE CORMORANT (PHALACROCORAX NIGER) IN DIFFERENT STUDY AREAS OF BANGLADESH
}

\author{
Habibon Naher \\ Department of Zoology, Jagannath University, Dhaka-1100, Bangladesh
}

\begin{abstract}
A study was done on nesting colonies of Little Cormorant (Phalacrocorax niger) in different study areas of Bangladesh from 2003 to 2005. The study sites were Eidgah in Cox's Bazar, Bhuyapur in Tangail, Bhairab and Tarail Upazilla in Kishorganj, Dimla in Nilfamari, Singair Upazilla in Manikganj and Matlab in Chandpur district. These sites were visited at regular interval to know about the characteristics of different nesting colonies and causes of their decline and threats for the Little Cormorant. The village markets and school areas were visited to know about the location of nests, different threats against them and information about the present situation of Little Cormorant and also for creation of awareness for their conservation. The nesting habitats of the Little Cormorant were situated in the homestead areas in all the cases. The highly preferred sites for nesting were near a pond $(75 \%)$. Bamboo (Bambusa arundinacea) was the highly preferred nesting trees $(25 \%)$. The nesting height varied from $8.84 \mathrm{~m}$ to $10.66 \mathrm{~m}$. Association of the Little Cormorant in the colony was found with Ardeaola grayii (30\%), Egretta garzetta (30\%), Mesophoyx intermedia (30\%), Casmerodius albus (5\%) and Pteropus giganteus (5\%). The nesting colonies of the Little Cormorant were destroyed by human $(92.9 \%)$ and river erosion $(7.1 \%)$. It was observed that awareness campaign will help for the conservation of the bird.
\end{abstract}

Key words: Population, causes of decline, Little Cormorant (Phalacrocorax niger), Bangladesh.

\section{INTRODUCTION}

Phalacrocorax niger popularly known as Little Cormorant is widely distributed in Bangladesh (IUCN 2000) belongs to the Family Phalacrocoracidae (Order Ciconiiformes). Among the total 38 species of cormorants and shags of the world, only 4 species are occur in India (Anon 2003) and 3 species of cormorants and 1 species of Darter are found in Bangladesh (Husain 1979, Sarker and Sarker 1988). Little Cormorant is found all over Kerala, India and distributed throughout the sub-continent except parts of North-east and the Himalaya (Grimmett et al. 1998) and extends east to Java, Indonesia (Wikipedia 2013). It forages singly or sometimes in loose groups in lowland freshwater bodies, including small ponds, large lakes, streams and sometimes coastal estuaries (Wikipedia 2013). Extensive works have been done on different species of cormorants in different countries of the world by different workers like, Lumsden and Haddow (1946), Stevens (1933), Snow (1960), Blaber and Wassenberg (1989), Williams (1942), Ross (1973), Platteeuw et al. (1995), 
Kopciewicz et al. 1999, Musll et al. 1999 etc. In Bangladesh, detailed works have been done on different aspects of the Little Cormorant (Naher and Sarker 2004, 2008a, b, 2010, 2011; Sarker and Naher 2002, 2003, 2007, 2008; Sarker et al. 2009; Naher et al. 2009). But little information is available on the characteristics features of nesting colonies as well as on threats against this bird in the countries. An attempt was made to study the nesting colonies and threats on the Little Cormorant $(P$. niger) in different parts of Bangladesh. The main objectives of this study were to know the nesting characters of the Little Cormorant in the country. Besides, the causes of decline in different areas and to know about the threats on breeding colonies and their population. Finally, to create awareness among local people about the conservation of this species and their nesting sites this information is essential.

\section{MATERIAL AND METHODS}

The study was done only in breeding season (May to October) in each year of 2003-2005. The study sites were Eidgah Upazilla in Cox's Bazar district, Bhuyapur Upazilla in Tangail, Bhairab and Tarail Upazilla in Kishorganj, Dimla in Nilfamari, Singair Upazilla in Manikganj and Matlab in Chandpur (Fig. 1). Observation was made in Matlab from 2003 to 2005, Eidgah and Dimla Upazilla in 2005 only and the rest areas were studied in 2004 and 2005. Immediate after getting the information about the nesting sites, the area was visited and as such, the study was done in various times. But once detected each area was visited once in a month. The areas were selected by distributing questionnaires. According to the answer of respondents, the breeding sites were searched, located and visited repeatedly. Height of nesting tree and nest heights were measured by a rope which was then measured by a meter scale. The number of nest was directly counted from the nesting colonies during breeding season only. GPS was taken for nesting sites but not taken for nesting trees. The village market and school areas were especially selected for creation of awareness for the conservation of birds in nature. Posters, class routines, badges and leaflets with conservation massages were distributed among the people and student in the study areas. Reviewing the Knowledge, Attitude and Practices (KAP) of the respondents regarding the bird and their conservation, information was gathered and awareness materials were prepared and discussed with them. As the nesting colonies were situated in the homestead areas, the land owner was requested to inhibit any type of loss, i.e. any destruction of eggs, nests, nestlings and young Cormorants and to ensure their securities to survive. 


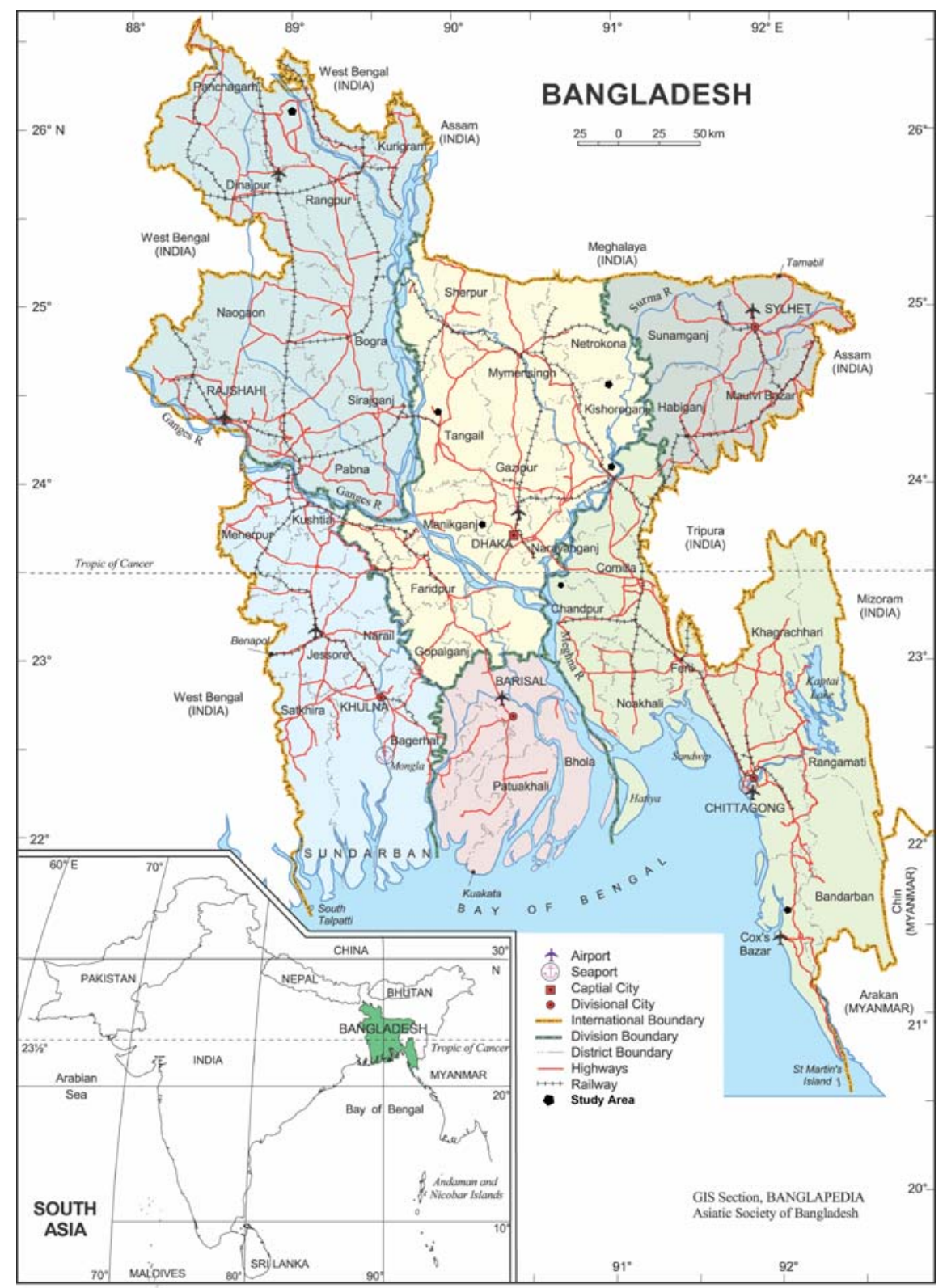

Fig. 1. Map of Bangladesh showing the study areas in $(\bullet)$.

\section{RESULTS AND DISCUSSION}

Nesting colonies: In the study areas, the nesting colonies were observed under different points Nesting habitat: In all the study areas it was observed (Table 1) that the Little Cormorant had chosen the homestead area as nesting habitat. Jerdon (1862) reported that cormorants bred occasionally in the midst 
of villages. Out of 8 colonies of present study, $6(75 \%)$ colonies were situated near a pond and $2(25 \%)$ colonies were on the bank of river. The Cormorants built their nests on trees standing in, near or away from water bodies as reported by different workers (Jerdon 1862, Whistler 1949, Ali and Futehally 1967, Ali 1977, Siriwannichkul 1981).

Nesting trees: Birds used different species of trees during nesting (Table 1). Bambusa arundinacea (25\%) was the highly preferred nesting trees followed by Mangifera indica (15\%), Bombax ceiba (15\%), Swietenia mahagoni (10\%), Sygygium cumini (10\%), Albizia procera (10\%), Ficus sp. (5\%), Polyalthia longifolia $(5 \%)$ and Cocos nucifera (5\%). Smythies (1953) described that they bred in Bamboo and Palms as well as in other trees. Hume and Oates (1890) reported that the Little Cormorant preferred Babool trees (Acacia arabica) for nesting. In the present study $3(37.50 \%)$ colonies were observed which are composed of two species of trees, $4(50 \%)$ colonies of three species of trees and $1(12.5 \%)$ with five species of trees. Nesting was not dependant on the species varieties. It was dependant on some closely situated trees. When one pair chose any tree for nesting in a specific area, other pairs selected the same tree without any hesitation until the nesting place was available in the same tree. After that the most adjacent tree was selected by other followers and so on. Even if any tree in between the nesting trees was avoided the other birds also avoided that tree. It was also found that if any Bambusa sp. was present in any area then it was the first priority for nesting of Little Cormorant and another tree Mangifera indica was their second choice. It may be the presence of more forked places. When Bambusa sp. and Cocos nucifera were used for nesting no human disturbance was found because of their incapability of returning there. When Mangifera indica was used, human disturbance was high $(38.7 \%$, no of hatchling $=137)$ for their easy access and caused destruction of eggs, nestlings and nests. The human disturbance was increasing as the availability of human access in the nesting trees.

Height of the nests and nesting trees: Average height of the nesting trees varied from 9.86 to $12.54 \mathrm{~m}(10.96 \pm 0.91)$ (Table 1). Nesting trees are often of small size in India (Whistler 1949). Average height of the nests from ground varied from 8.84 to $10.66 \mathrm{~m}(9.66 \pm 0.7)$ in the present study. Thomson (1965) reported that the nests may be on rocky islets, on cliff ledges or in trees and some bird species use different sites according to locality. When the nests were built at the peak forked places of trees the human disturbance was zero because they usually could not reach there. 


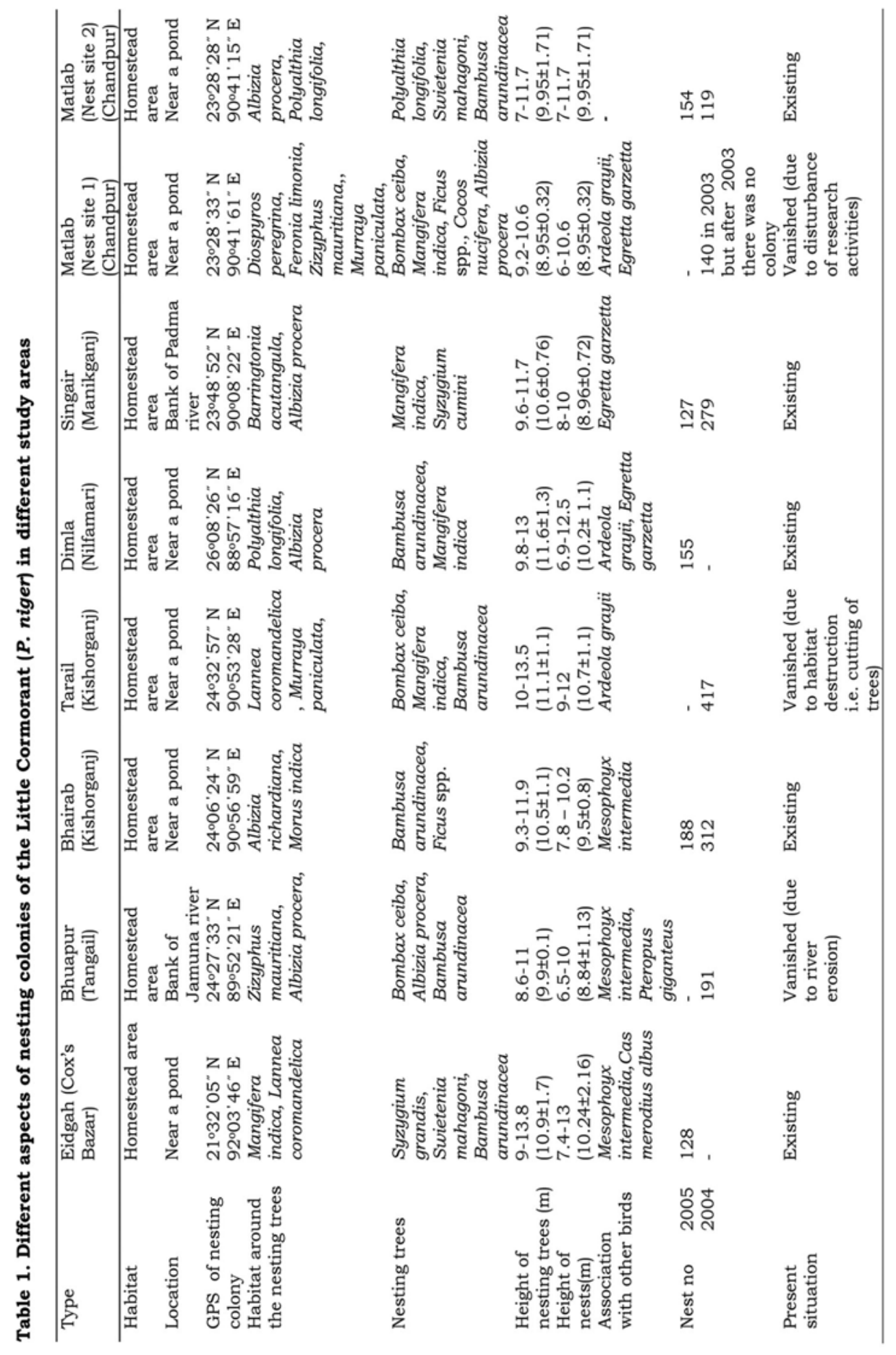


Association with other birds: Different species of birds, like Ardeola grayii (30\%), Egretta garzetta (30\%), Mesophoyx intermedia (30\%), Casmerodius albus $(5 \%)$ and Pteropus giganteus (5\%) (Table 1) built their nests in association of Little Cormorants' nests. Smythies (1953) and Ali (1977) reported that the Little Cormorant built nests in mixed colonies of Darters, Egrets, Storks, etc. These birds breed gregarious in trees, often joining other waterbirds at heronries (Wikipedia 2013). They may built nests beside Ardeola grayii (30\%), Egretta garzetta in colonies (Naher et al.2009).

Causes of decline: Although awareness campaign was made in all the study areas yet the population of the Little Cormorant's breeding colony in all the study areas found declined except in one area (Table 1). Here the landowner was highly motivated and protected the nesting colony by taking initiatives as well as continuously guarding the sites. The nesting colonies of the Little Cormorant were found destroyed by human (92.9\%) and river erosion $(7.1 \%)$. Human being often destroyed the nests for various reasons (Fig. 2). Trapping and hunting were also occurred for various purposes (Fig. 3). Habitat destruction was mainly caused by cutting of the nesting trees which were also used housing, to earn money, and for expansion of agricultural lands and roads. Developmental works, illegal trawling, construction of ports, marinas and sea walls, uncontrolled anchoring of yachts and sand extractions for beach regeneration may affect the habitat availability for Shag as observed by European Commission (1999).

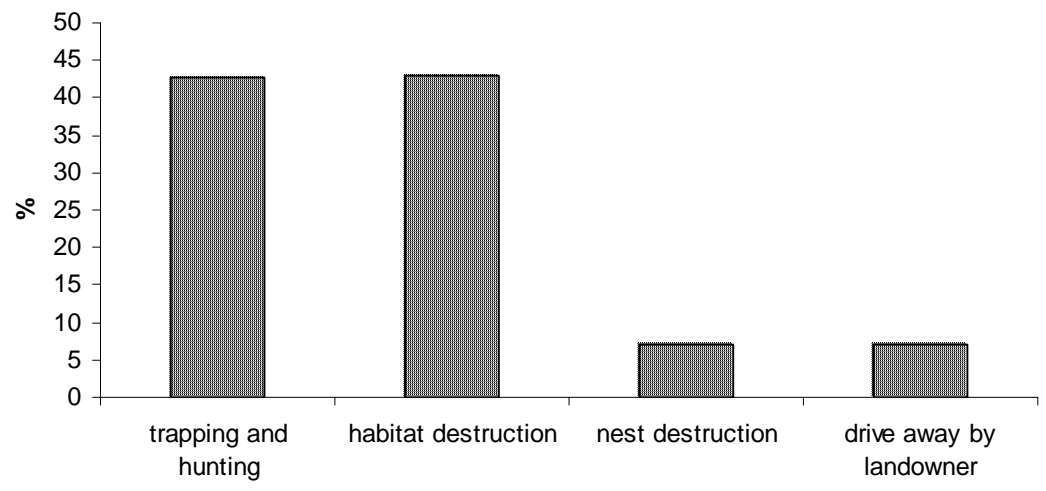

Fig. 2. Causes of decline due to human interference

Nest destruction by human was another cause of decline of the birds. The house holds members were mainly responsible for this. They used the nests as fuel materials as each nest rather contained about 1 to $1.5 \mathrm{~kg}$ materials (Sarker et al. 2009). Stealing by local people from the nesting colonies was the main cause of decline of Little Cormorant's population as found in Chandpur of 
Bangladesh (Sarker et al. 2009). The disturbance made by the landowners was another reason. As the Little Cormorant built their nests in homestead area beside the aquatic body in the present study, the landowner felt disturbed because the birds are very noisy during nesting period. Moreover, the nesting trees and the areas under the nesting trees were plastered with the bird's droppings. Even they complained that the houses roofs which were made by tin were also harmed by the droppings. When they selected the fruiting trees for nesting, the fruits' production was not possible. Besides, the nesting areas became fishy stink. Thus the land owner tried to drive away them at the beginning of the nesting period if the birds selected their homestead areas. According to Ypte (2013), cormorants have sometimes been persecuted by fishermen because of the belief that they eat huge quantities of fish, especially in rivers where they were supposed to prefer young salmon and trout, but research has shown that cormorants seem to favour flat fish and eels, taking only small amounts of the more saleable fish. In the Far East, some fishermen make use of the cormorant's expertise, by training it to catch fish for them (Ypte 2013).

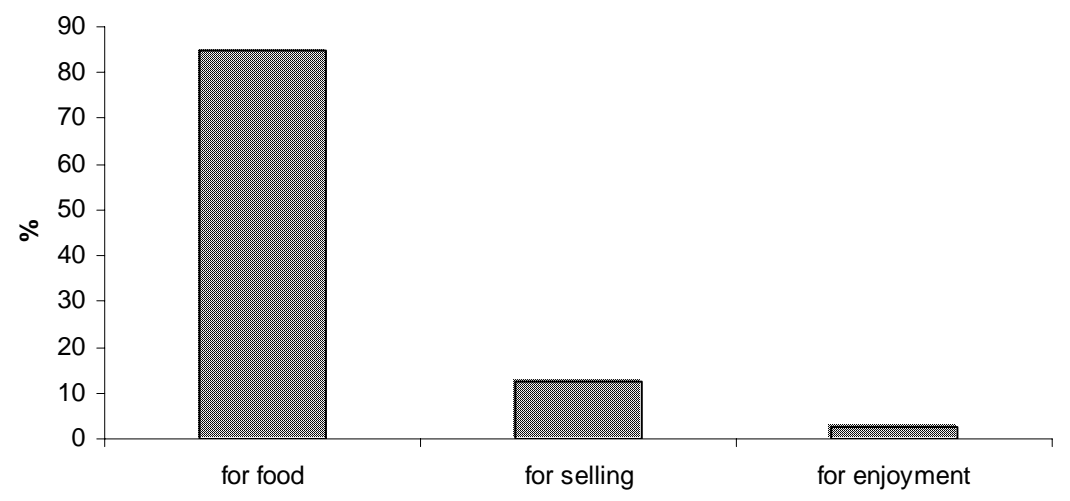

Fig. 3. Causes of trapping and hunting of Little Cormorant

Research activities may be sited as another reason for their (nestlings) destruction. In 2003, nests were frequently visited for detail study of breeding in Matlab-1. Probably for this reason, no nests were built there in 2004 and 2005, while another nesting colony was found $0.5 \mathrm{~km}$ away from the old nesting area. Guyot (1993) described that the colonies of Mediterranian Shag (Phalacrocorax aristotelis) were severely affected by frequent visits to the colonies. European Commission (1999) reported that tourist activities, the lack of effective protection, bird watching and research activities could represent a serious threat for the Mediterranian Shag. Weseloh and Miller (1999) stated that weekly research activity and illegal shooting and nest destruction were the causes of decline of Double-crested Cormorant's population at the Little Galloo Island in 
the US Eastern Basin. Some fishing methods such as gill nets and fish traps, illegal persecution, incidental oil spills or illegal washing of tanks, habitat loss, over fishing, predation by introduced mammals, and competition with other species may cause threats to shag population in many parts of the world (Lambertini and Leonzio 1986, Aguilar 1991, European Commission 1999). Besides, common cormorants are affected by oil pollution, caused by shipwrecks or by ships which discharge their oil at sea illegally (Ypte 2013). It was also reported that cormorants have also suffered when fishing in the location of an oil slick; as oil clogs their feathers they are unable to fly and swim and, as a result, they drown and birds may also die of poisoning if they swallow oil (Ypte 2013).

In the study period, $3(37.5 \%)$ colonies were absolutely vanished (Table 1) out of 8 colonies, on the basis of which it may be assumed that throughout the country each and every year a good number of colonies are becoming vanished as a result of different factors mentioned earlier.

Destructive activities are the main cause of the declination of the population of this species. For nesting the Little Cormorants' need tall trees around or adjacent to the water bodies which were also destroyed by humans for the fulfillment of their needs. Thus creation of awareness among the local people as well as protection is the main instrument to conserve the Little Cormorant population in nature.

Acknowledgement: The authors are grateful to the villagers of the study areas for giving permission to conduct the study. They also grateful to the Ministry of Science, Information and Communication Technology for funding the research.

\section{LITERATURE CITED}

AGUILAR, J.S. 1991. Resum de I'Atlas d'ocells marins de les Balears, 1991. Anuari Ornitológic de les Balears. Vol 6. G.O.B. Palma de Mallorca.

ALI, S. 1977. The Book of Indian Birds (10th edition). Bombay Natural History Society, Bombay. India. xvii $+175 \mathrm{pp}$.

ALI, S. and FUTEHALlY, L. 1967. Common birds. National book trust. New Delhi 110016, India. pp. ix +117 .

ANON. 2003. Wikipedia. Available at http://en.wikipedia.org/wiki/Cormorant\# Species. Accesses date: $15-02-2003$.

BLABER, S.J.M. and WASSENBERG, T.J. 1989. Feeding ecology of the piscivorous birds Phalacrocorax varius, P. melanoleucos and Sterna bergii in Moreton Bay, Australia: dites and dependence on trawler discard. Mar. Bio. 101: 1-10.

EUROPEAN COMMISSION, 1999. Species Action Plan for the Mediterranean Shag Phalacrocorax aristotelis desmarestii in Europe. Final Draft, December 1999. Prepared by Birdlife International on behalf of the European Commission. 
http://web.tiscali.it/cormorants/pdf/cormo_docs/actionplan-phalacrocorax_desmaresti.pdf-

GRIMMETT, R, INSKIPP, C. and INSKIPP, T. 1998. Birds of the Indian Subcontinent. Oxford University Press. Delhi. pp. 888.

GUYOT, I. 1993. Breeding distribution and number of Shag (Phalacrocorax aristotelis desmarestit) in the Mediterranean. In Aguilar, J.S., Monabailliu, X., Paterson, A. M. Estatus y ConsrvaciÛn de Aves Marinas. Actas del II Simposio MEDMARAVIS. SEO. Madrid.

HUME, A.O. and OATES, E.W. 1890. Nests and eggs of Indian birds. Vol. III, $2^{\text {nd }}$ ed.R.H. Porter, 18 princes street, Cavendish square, W. London.

HUSAIN, K. 1979. Birds of Bangladesh. Department of Films and Publications, Government of the Peoples Republic of Bangladesh. 84 pp.

IUCN. 2000. Red Book of Threatened Birds of Bangladesh. IUCN Bangladesh Country Office, Dhaka, Bangladesh. xi+116 pp.

JERDON, T.C. 1862. The Birds of India. Vol. 11, part 1. The Military orphan press, Calcatta. xiv+535 pp.

KOPCIEWICZ, P., NITECKI, C., BZOMA, S. and STEMPNIEWICZ, L. 1999. Breeding success of cormorants Phalacrocorax carbo sinensis in the colony at Katy Rybackie (N Poland). 23rd Annual Meeting and Workshops 8 - 12 November 1999, Palazzo Congressi, Grasdo, Italy. Waterbird Conservation and Management.

http://web.tiscali.it/sv2001/cormo_abstract/sunti_cwgrado.htm

LAMBERTINI, M. and LEONZIO, C. 1986. Pollutant levels and their effects on Mediterranean seabirds. In MEDMARAVIS and Monabailliu, X. Medi. Avif. : 359-378. Springer-Verlag. BerlinHeidelberg.

LUMSDEN, W.H.R. and HADDOW, A. J. 1946. The food of the Shag (Phalacrocorax aristotelis) in the Clyde sea area. J. Anim. Ecol. 15: 35-42.

MUSLL, P., CEPAK, J. and MARTINCOVA, M. 1999. Great cormorant in the Czech Republic: Populations status and Action plan. 23rd Annual Meeting and Workshops 8 - 12 November 1999, Palazzo Congressi, Grasdo, Italy. Waterbird Conservation and Management.

http://web.tiscali.it/sv2001/cormo_abstract/sunti_cwgrado.htm

NAHER, H. and SARKER, N.J. 2004. Population Ecology of the Little Cormorant, Phalacrocorax niger in a colony. ECOPRINT (An International Journal of Ecology). 11(1): 65-68.

NAHER, H. and SARKER, N.J. 2008a. A comparison of some aspects of breeding of the Little Cormorant (Phalacrocorax niger) in nature and in captivity. Bangladesh J. Zool. 36(1): 101 -110.

NAHER, H. and SARKER, N.J. 2008b. Display and sexual activities of the Little Cormorant, Phalacrocorax niger (Ciconiiformes: Phalacrocoracidae) in captivity. Saudi J. Biol. Sci. 15(1): 8186.

NAHER, H. and SARKER, N.J. 2010. Morphometric analysis of the Little Cormorant (Phalacrocorax niger). Bangladesh J. Zool. 38(1): 113-118.

NAHER, H. and SARKER, N.J. 2011. Growth and development of Little Cormorant Phalacrocorax niger (Viellot), Bangladesh. Bangladesh J. Zool. 39(1): 69-76.

NAHER, H., SARKER, N.J., RAHMAN, M.K. and KHAN, S.I. 2009. Breeding biology of the Little Cormorant Phalacrocorax niger (Pelecaniformes: Phalacrocoracidae) in Bangladesh. $J$. Threatened Taxa. 1(4): 221-225. 
PlATTEEUW, M., KOFFIJJBERG, K. and DUBBELDAM, W. 1995. Growth of cormorant, Phalacrocorax carbo sinensis chicks in relation to brood size, age ranking and parental fishing effort. Ardea. 83(1): 235-245.

ROSS, P.X. 1973. Notes on wintering Great Cormorant in Nova Scotia. Can. Fie. Nat. 88: 493-494.

SARKER, N.J. and NAHER, H. 2002. Experimental studies on food habits of the little cormorant, Phalacrocorax niger (Vieillot). Bangladesh J. Zool. 30(2): 173 - 182.

SARKER, N.J. and NAHER, H. 2003. Daily activities of little cormorant, Phalacrocorax niger (Vieillot), (Ciconiiformes: Phalacrocoracidae) in captivity. J. Asiat. Soc. Bangladesh, Sci. 29(2): 55 - 62

SARKER, N.J. and NAHER, H. 2007. Nest and nest building behaviour of the Little Cormorant (Phalacrocorax niger). Bangladesh J. Zool. 35(2): 269-274.

SARKER, N.J. and NAHER, H. 2008. Food of the nestlings of the Little Cormorant, Phalacrocorax niger (Vieillot). J. Asiat. Soc. Bangladesh, Sci. 34(2): 187-194.

SARKER, N.J. NAHER, H. and KHAN, S.I. 2009. Conservation problems of the Little Cormorant (Phalacrocorax niger) in Bangladesh. Bangladesh J. Zool. 37(2): 319-328.

SARKER, S.U. and SARKER, N.J. 1988. Wildlife of Bangladesh (A systematic list with status, distribution and habitat). The Rico Printers, Nilkhet Babupura, Dhaka, Bangladesh.

SIRIWANNICHKUL, O. 1981. Food habits and breeding biology of little cormorant (Phalacrocorax niger). Kasetsart Univ. Bangkok. Thailand.

SMYTHIES, B.E. 1953. The Birds of Burma. 2nd edition. Oliver and Boyd, Edinburgh: Tweeddale Court, London. xliii+668 pp.

SNOW, B.K. 1960. The breeding biology of the Shag Phalacrocorax aristotelis on the Island of Lundy, Bristol Channel. Ibis. 102: 554 - 575.

STEVENS, G.A. 1933. The food consumed by Shags and Cormorants around the shore of cornwall (England). J. Mar. Biol. Ass. 19: 277-292.

THOMSON, A.L. 1965. A new dictionary of birds. Thomas Nelson (Printers) Ltd, London and Edinburgh. pp. 928.

WESELOH, D.V.C. and MILLER, R.L. 1999. The status of the double-crested cormorant (Phalacrocorax auritus) on lake onatrio in 1999: at the beginning of management activities. 23rd Annual Meeting and Workshops on Waterbird Conservation and Management, 8-12 November 1999, Palazzo Congressi, Grasdo, Italy.

WHISTLER, H. 1949. Popular handbook of Indian Birds. 4th edition. Gurney and Jackson, Edinburgh: Tweeddale Court, London. xxviii+560 pp.

WIKIPEDIA. 2013. https://en.wikipedia.org/wiki/Little_Cormorant, accessed date 22/04/2013.

WILLIAMS, L. 1942. Display and sexual behaviour of the Brandt Cormorant. The Con. 44(3): 86-104.

YPTE. 2013. http://www.ypte.org.uk/animal/cormorant/65, accessed date 22/4/2013.

(Manuscript received on 18 June 2013; revised on 24 April 2014) 